\title{
PEMBELAJARAN MATEMATIKA MENGGUNAKAN PENDEKATAN PROBLEM POSING BERBASIS KOMPUTER PADA SISWA SMA KELAS $X$
}

\author{
Oleh: \\ 1) Muhammad Win Afgani, ${ }^{2)}$ Bagus Ardi Saputro, ${ }^{3)}$ Jero Budi Darmayasa \\ 1,2,3) Mahasiswa Sekolah Pascasarjana Universitas Pendidikan Indonesia \\ 19afgani@student.upi.edu, ${ }^{2}$ bagusardisaputro@ @student.upi.edu, ${ }^{3}$ jeromath@ student.upi.edu
}

\begin{abstract}
ABSTRAK
Penelitian ini bertujuan untuk mengetahui bagaimana untuk menghasilkan materi pembelajaran matematika problem possing berbasis komputer dan untuk mengetahui bagaimana kuantitas dan kualitas pertanyaan siswa dari masalah pendekatan problem possing berbasis komputer. Pertanyaan dan respon siswa dikumpulkan dari 35 siswa kelas satu SMA di Bandung. Data dianalisis dengan deskriptif dengan menggunakan rubrik Leung dan taksonomi Bloom. Untuk menghasilkan materi problem posing berbasis komputer, pertama, guru harus memilih konsep yang diharapkan dapat mengembangkan kemampuan siswa. Setelah itu, guru mencari konteks yang sesuai dengan konsep. Setelah konteks yang dipilih dan cocok tersebut, guru harus memilih software untuk melakukan ide dalam bentuk yang dinamis. Hasil penelitian ini menunjukkan bahwa dari 240 pertanyaan yang diberikan oleh siswa, hanya 35\% yang masuk akal dan cukup masalah matematika. Dari 35\% pertanyaan tersebut menunjukkan bahwa $75 \%$ siswa di tingkat pemahaman berdasarkan Bloom taksonomi. Dari $75 \%$ siswa yang merespon tersebut menunjukkan bahwa mereka senang terhadap materi yang menggunakan pendekatan problem possing matematika berbasis komputer.
\end{abstract}

Kata Kunci : Pembelajaran Matematika, Problem Possing, Komputer

\begin{abstract}
This study aims to know how to produce mathematics problem posing material based on computer and to know how the quantity and quality of students' question from mathematics problem posing based on computer. Students' questions and respond is collected from 35 first grade students of senior high school in Bandung. The data is analysed with descriptively by using Leung's rubric and Bloom taxonomy. To produce problem posing material based on computer, first, teacher must choose a concept that wish to be gifted to students. After that, the teacher searchs a context that according to the concept. After the context is selected and match with it, the teacher must choose a software to perform the idea in dynamic form. The result of this study shows that there is 240 questions that pose by students, only $35 \%$ is plausible and sufficient mathematics problem. From $35 \%$ questions, it shows that $75 \%$ students is in understanding level based on Bloom taxonomy. From the questioner, $75 \%$ students' respond shows that they are happy toward material presentation by mathematics problem posing approach based on computer.
\end{abstract}

Keywords: Learning Mathematics. Problem Posing, Computer.

\section{PENDAHULUAN}

Inovasi dalam pembelajaran matematika sangat dibutuhkan untuk saat ini. Inovasi dapat berupa pendekatan pembelajaran ataupun penilaian hasil belajar. Salah satu inovasi yang dapat dilakukan dalam pendekatan pembelajaran adalah dengan menerapkan Pendekatan Problem Posing. Polya (1994, dalam Sumarmo 2015) menyatakan bahwa pengajuan masalah 
atau pertanyaan dalam memecahkan masalah matematik merupakan hal yang penting. Problem Posing adalah proses personal siswa dalam mengkonstruksi pertanyaan-pertanyaan matematika berdasarkan pengalaman matematika mereka (Stoyanova \& Ellerton, 1996). Duncker (1945, dalam Sumarmo 2015) menyatakan bahwa Problem Posing adalah aktivitas mengkonstruksi problem baru atau masalah baru dari suatu konteks matematika atau memformulasi ulang masalah yang diberikan. Dari kedua pendapat tersebut ada dua pendekatan yang mungkin dilakukan dalam pembelajaran matematika, yaitu 1) menyajikan konteks matematika atau siswa diminta untuk mengajukkan pertanyaan-pertanyaan berdasarkan pengalaman mereka, 2) mengajukkan masalah kemudian siswa membuat pertanyaan-pertanyaan baru yang mendukung proses pemecahan masalah. Permasalahan yang kedua sudah dijelaskan oleh Leung (1993).

Melalui dua pendekatan itu, guru akan menyediakan beragam materi dalam proses pembelajaran berbasis Problem Posing. Namun, pendekatan Problem Posing yang diterapkan di kelas cenderung bersifat konvensional. Sementara, dengan memperhatikan perkembangan Teknologi Informasi dan Komunikasi (komputer) memungkinkan dilakukan inovasi dalam pembelajaran matematika menggunakan Problem Posing. Inovasi yang dimaksud yaitu penggunaan berbagai aplikasi komputer dalam pembelajaran matemaKomputera. Inovasi itu muncul dikarenakan siswa tidak mempunyai beragam sudut pandang yang dinamis, sehingga hanya menyajikkan sedikit masalah yang baru (Fukuda dan Kakihana, 2009). Penggunaan komputer dalam pembelajaran matematika dengan pendekatan Problem Posing didukung oleh Brown \& Walter (2005) yang menyatakan bahwa komputer dapat membantu siswa mengeksplorasi dan membuat dugaan yang lebih baik serta memungkinkan komputer memberikan banyak contoh yang positif, dalam hal ini memberikan dugaan yang baru.

Pembelajaran Matematika berbasis Komputer dengan Pendekatan Problem Posing dapat menggunakan berbagai macam software seperti GeoGebra, Speadsheet/ Microsoft Office Exel, Maple, Cabri dan lain sebagainya. Materi yang didisain dalam penelitian ini menggunakan GeoGebra. Berdasarkan uraian tersebut di atas maka akan dibahas 1) bagaimana menghasilkan materi problem posing berbasis komputer, 2) bagaimana kuantitas dan kualitas pertanyaan dari materi problem posing berbasis komputer.

\section{KAJIAN PUSTAKA}

\section{A. Problem Possing Matematika}

Stoyanova \& Ellerton (1996) mengemukakan bahwa problem posing matematika didefinisikan sebagai proses yang didasarkan pada pengalaman matematika siswa dimana dia mengkonstruk interpretasi secara individual terhadap situasi nyata dan memformulasinya sebagai permasalahan matematika yang bermakna. Definisi tersebut diadopsi dalam penelitian Herawati, Siroj \& Basir (2010) yang menyatakan pembelajaran dengan pendekatan problem posing adalah pembelajaran yang menekankan pada siswa untuk membentuk/mengajukan soal berdasarkan informasi atau situasi yang diberikan. Informasi yang ada diolah dalam pikiran dan setelah dipahami maka peserta didik akan bisa mengajukan pertanyaan. Sedangkan Haji (2011) mendefinisikan pendekatan problem posing adalah memberikan kesempatan kepada siswa untuk menyampaikan (merumuskan) suatu soal matematika yang lebih sederhana dalam rangka menyelesaikan suatu soal yang kompleks (rumit). Kedua definisi tersebut semuanya sesuai dengan definisi dari penelitian Susanti, Sukestiyarno \& Sugiharti (2012) yang merujuk 
definisi dari Sheikhzade (2009) yang menyatakan bahwa membuat masalah dengan melibatkan dan menghasilkan masalah baru dan pertanyaan untuk mengeksplorasi tentang situasi tertentu, serta merumuskan masalah selama pemecahan masalah untuk berhubungan dengan itu.

Selanjutnya, Susanti, Sukestiyarno \& Sugiharti, E. (2012) dan Robiyana (2013) menyatakan bahwa prestasi belajar siswa SMP yang belajar dengan model/metode problem posing lebih baik dari pada prestasi belajar siswa mdengan metode konvensional. Lebih khusus dari itu, menurut Herawati, Siroj \& Basir (2010) kemampuan pemahaman konsep matematis siswa pada pembelajaran problem posing lebih tinggi dari pada pembelajaran konvensional. Walaupun begitu, pembelajaran problem posing lebih berpengaruh terhadap siswa berkemampuan tinggi dari pada siswa berkemampuan sedang ataupun rendah. Kemudian, Haji (2011) memberikan problem yang kompleks kepada siswa, kemudian mereka menggunakan pendekatan problem posing dalam menyelesaikannya. Hasil penelitian menunjukkan hasil belajar matematika siswa, tingkat pemahaman soal siswa, variasi cara menyelesaikan soal siswa lebih baik dari pada teman mereka pada kelas konvensional.

\section{B. Tahap Pembelajaran Problem Posing Berbasis Komputer}

Beberapa tahap pembelajaran problem posing menggunakan komputer

1) Pertama, Guru memberikan masalah dalam bentuk aktivitas, kemudian siswa diminta menyusun pertanyaan. Pada tahap kedua, Guru memvisualisasikan permasalahan dalam komputer atau siswa merekonstrusksi permasalahan menggunakan software aplikasi, kemudian siswa diminta menyusun pertanyaan kembali. Guru memberikan komentar pada pertanyaan yang diajukan siswa. Siswa memperbaiki pertanyaan sehingga cukup informasi dan dapat diselesaikan. Selanjutnya, siswa diberi kesempatan untuk memilih dan menjawab pertanyaan yang telah dikumpulkan. Penelitian yang menerapkan tahap pembelajaran ini dilakukan oleh Ferrigo Software yang digunakan adalah Microsoft Excel dan GeoGebra. Hasil penelitiannya menunjukkan bahwa siswa memberikan respon yang baik terhadap pembelajaran. Kemudian, Fukuda dan Kakihana melaporkan bahwa siswa memahami masalah lebih dalam dengan merekonstruksi ekspresi dalam masalah; siswa mendapatkan beragam intuisi, dan eksplorasi yang luas; siswa dapat menemukan dua atau lebih metode penyajian masalah dan untuk mengkonfirmasi penyelesaian yang diperkirakan melalui percobaan; siswa dapat mengembangkan suatu sudut pandang dinamis dimana masalah dapat diubah dalam situasi khusus; dan siswa dapat membuat aspek masalah yang diekspresikan secara simbolis atau membuat generalisasi.

2) Guru memberikan masalah dalam bentuk simulasi komputer, kemudian siswa diminta menyusun pertanyaan. Guru memberikan komentar pada pertanyaan yang diajukan siswa. Siswa memperbaiki pertanyaan sehingga cukup informasi dan dapat diselesaikan. Selanjutnya, siswa diberi kesempatan untuk memilih dan menjawab pertanyaan yang telah dikumpulkan. Tahap pembelajaran ini merupakan modifikasi dari tahap pembelajaran yang pertama.

3) Guru merancang permasalahan dalam komputer, kemudian siswa diminta menyusun pertanyaan. Pertanyaan tersebut dihimpun dalam sistem komputer, melalui jaringan online atau offline, pertanyaan disebarluaskan ke siswa lain sehingga siswa dapat.memilih pertanyaan untuk diselesaikan. 
Pembelajaran secara online dilakukan dalam penelitian Beal \& Cohen (2012). Mereka mengembangkan aplikasi website yang mendukung aktivitas siswa dalam belajar. Aplikasi tersebut untuk memfasilitasi siswa yang mungkin baru menemukan dan membuat pertanyaan di tempat yang berbeda pada waktu diluar jam pelajaran reguler, kemudian dia ingin membaginya dengan temannya dan ingin melihat serta mencoba menjawab pertanyaan yang dibuat temannya yang relatif terbatas pada aktivitas kelas tradisional. Pembelajaran secara offline dirancang oleh Chang, et al. (2011). Pembelajaran dibuat dalam suatu sistem komputer dimana sistem ini memberikan para siswa kesempatan untuk merefleksi problem posing yang dibuatnya dengan mengujinya sehingga meningkatkan kemampuan problem posing mereka. Siswa dapat kembali berulang-ulang untuk menyelesaikan masalah dari problem posing sehingga memperbaiki skornya. Melalui komentar dan umpan balik dari guru yang tersimpan dalam sistem, siswa dapat memperbaiki kemampuan problem posing-nya.

Studi ini menerapkan langkah-langkah pembelajaran yang kedua, tetapi hanya sampai pada siswa menyusun pertanyaan. Pertanyaan-pertanyaan yang terkumpul dianalisa mengenai kualitasnya. Merujuk studi yang dilakukan Zakaria, et. al. (2014), ada tiga tahapan, yaitu 1) mengidentifikasi masalah apakah dapat diselesaikan, 2) mengidentifikasi konten masalah masuk dalam kategori apa, dan 3) memberikan skor berdasarkan kreatifitas siswa, sedangkan studi ini hanya sampai tahap ke-2 dan mengidentifikasi jenjang kognitif taksonomi bloom terhadap pertanyaan-pertanyaan yang diajukan siswa. (Widodo \& Pujiastuti, 2006).

\section{METODE PENELITIAN}

Penelitian ini adalah penelitian deskriptif. Adapun subjek penelitiannya yaitu siswa SMA Kelas X di salah satu sekolah kota Bandung sebanyak 35 orang. Teknik pengumpulan data menggunakan dokumentasi dan angket terbuka. Data dokumentasi berupa hasil problem posing yang diajukan siswa. Data tersebut dianalisis menggunakan rubrik Leung (2012) dan taksonomi Bloom. Data angket terbuka digunakan untuk mengetahui respon siswa terhadap materi yang disajikan. Kedua data tersebut dianalisis secara deskriptif.

\section{HASIL PENELITIAN DAN PEMBAHASAN}

Disain materi diawali dengan memilih konsep yang ingin disampaikan, kemudian mencari konteks yang sesuai dengan konsep tersebut. Setelah konteks terpilih dan bersesuaian maka dipilihlah software yang tepat untuk merepresentasikan gagasan kedalam bentuk lain yang dinamis. Untuk lebih jelasnya, lihat gambar berikut:

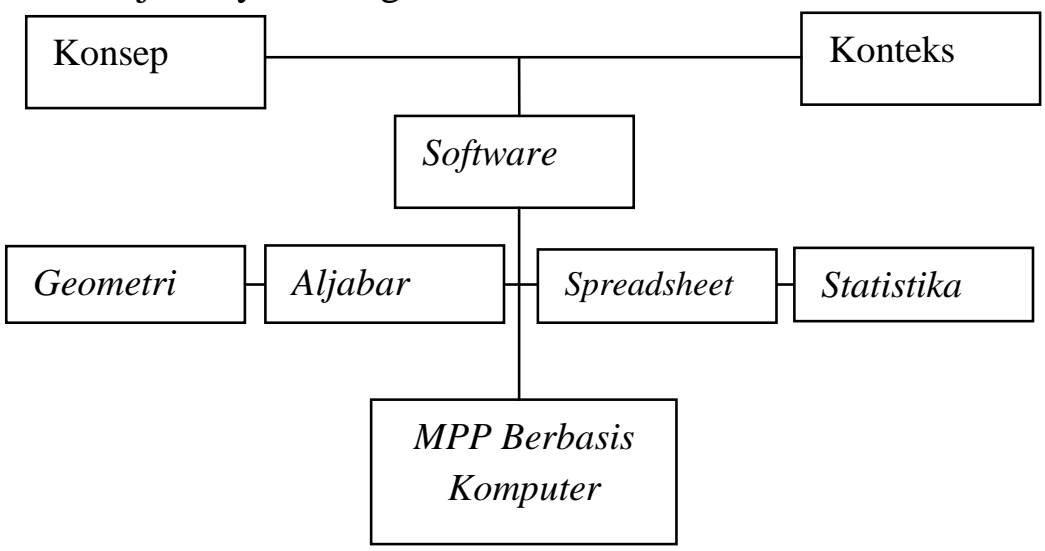




\section{Gambar 1. Skema disain materi MPP Berbasis Komputer}

Disain MPP berbasis Komputer yang sudah dihasilkan disajikan dalam gambar 2 berikut ini:

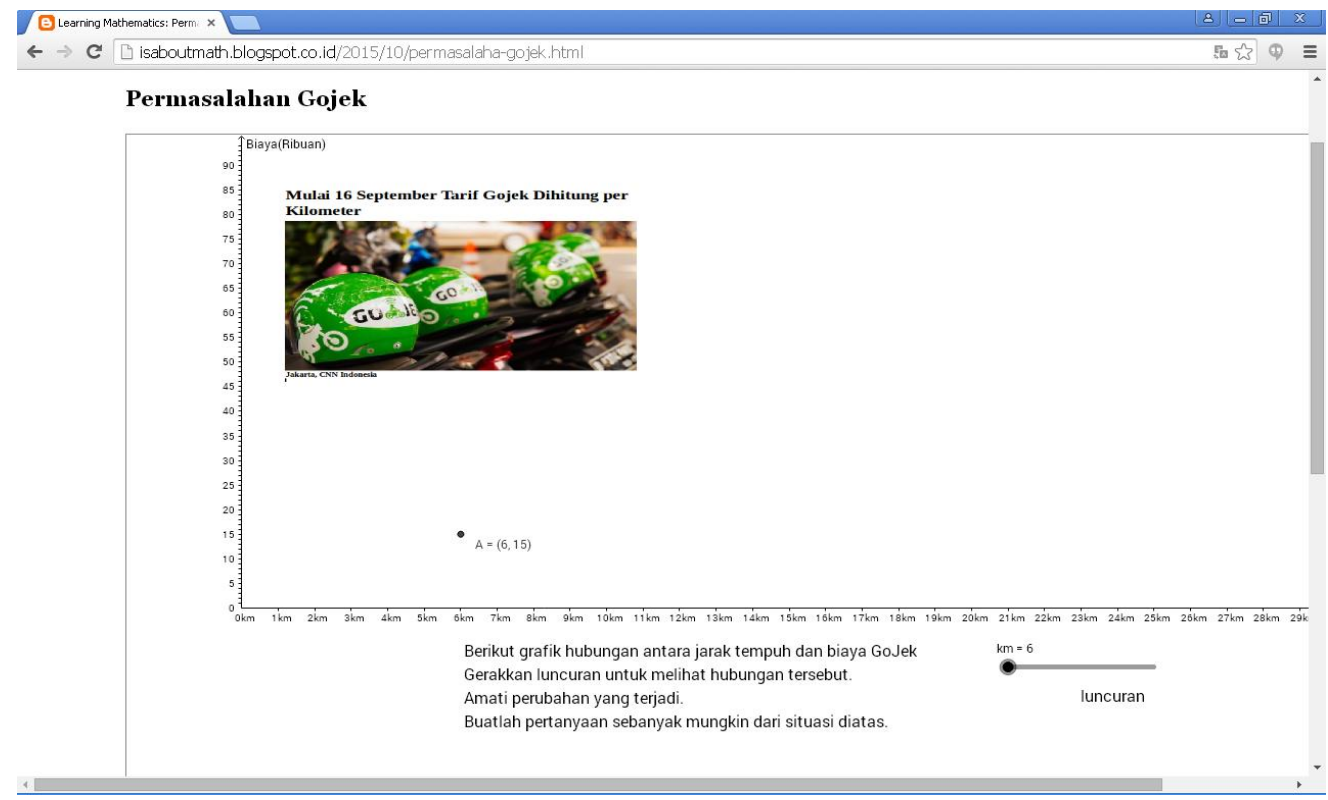

Gambar 2. Problem sehari-hari yang disajikan secara Problem Posing.

Setelah materi ini diuji coba, didapat pertanyaan-pertanyaan yang dialisis untuk melihat kuantitas dan kualitas pertanyaan tersebut. Analisis merujuk kepada rubrik Leung (2012). Hasil yang didapat menunjukkan bahwa terdapat 240 pertanyaan yang dibuat oleh 35 siswa. $35 \%$ pertanyaan merupakan masalah matematika yang cukup informasi. Permasalahan dalam kategori ini dapat digunakan untuk mengantar siswa untuk belajar materi fungsi, sedangkan sisanya merupakan pertanyaan yang tidak dapat digunakan dalam pembelajaran.I

Tabel 1. Contoh Hasil Kategorisasi Problem Posing yang diajukan siswa

\begin{tabular}{|c|c|c|}
\hline No & Kategori & Problem Posing yang diajukan siswa \\
\hline 1 & Bukan Suatu Masalah & $\begin{array}{l}\text { Apakah penumpang bisa mengendarai motor } \\
\text { Gojek tersebut? }\end{array}$ \\
\hline 2 & Bukan masalah matematika & $\begin{array}{l}\text { Apakah dengan mengganti tarif harga Gojek } \\
\text { menandakan Gojek sudah sukses meraup } \\
\text { pelanggan? }\end{array}$ \\
\hline 3 & $\begin{array}{l}\text { Masalah matematika yang } \\
\text { tidak mungkin diselesaikan }\end{array}$ & $\begin{array}{l}\text { Apa keuntungan dan kerugian untuk perusahaan } \\
\text { Gojek dan pelanggan apabila tarif Gojek dihitung } \\
\text { perkilometer? }\end{array}$ \\
\hline 4 & $\begin{array}{l}\text { Masalah Matematika yang } \\
\text { tidak cukup informasi }\end{array}$ & $\begin{array}{l}\text { Apakah kecepatan perpindahan dari satu titik ke } \\
\text { titik selanjutnya konstan? }\end{array}$ \\
\hline 5 & $\begin{array}{l}\text { Masalah matematika yang } \\
\text { cukup informasi }\end{array}$ & $\begin{array}{l}\text { Jika kita memiliki uang Rp. } 20.500 \text {,- berapa } \\
\text { kilometer yang bisa kita capai? }\end{array}$ \\
\hline
\end{tabular}


Hasil keseluruhan kategorisasi problem posing yang diajukan siswa dapat dilihat pada diagram di bawah ini.

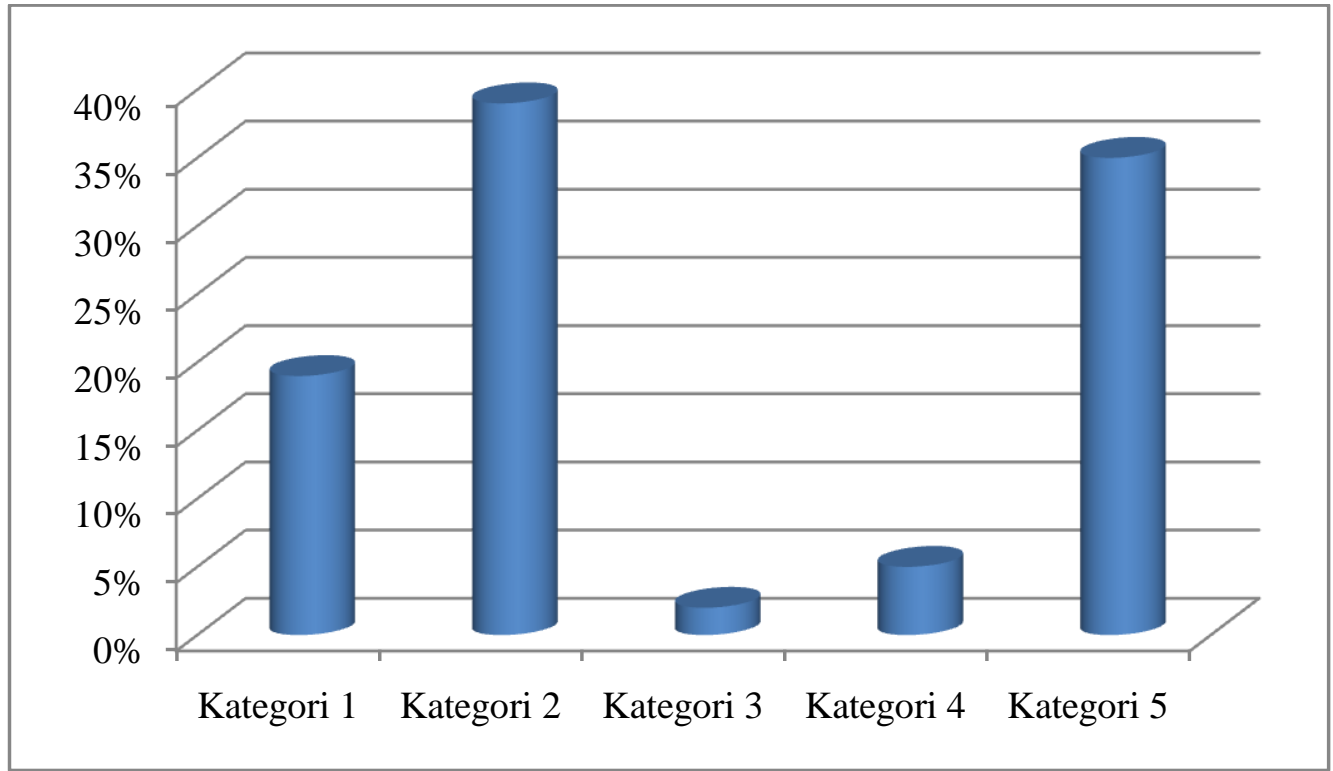

Gambar 3. Diagram Persentase Kategorisasi Problem Posing Siswa

Hasil analisis jenjang kognitif taksonomi bloom terhadap 35\% pertanyaan yang merupakan masalah matematika dan cukup informasi yang diajukan siswa menunjukkan bahwa $75 \%$ masih dalam tingkat pemahaman, artinya kebanyakan siswa masih terbiasa menyelesaikan soal-soal yang bersifat pemahaman. Berikut Hasil keseluruhan jenjang kognitif taksonomi bloom terhadap problem posing kategori 5 yang diajukan siswa dapat dilihat pada diagram di bawah ini.

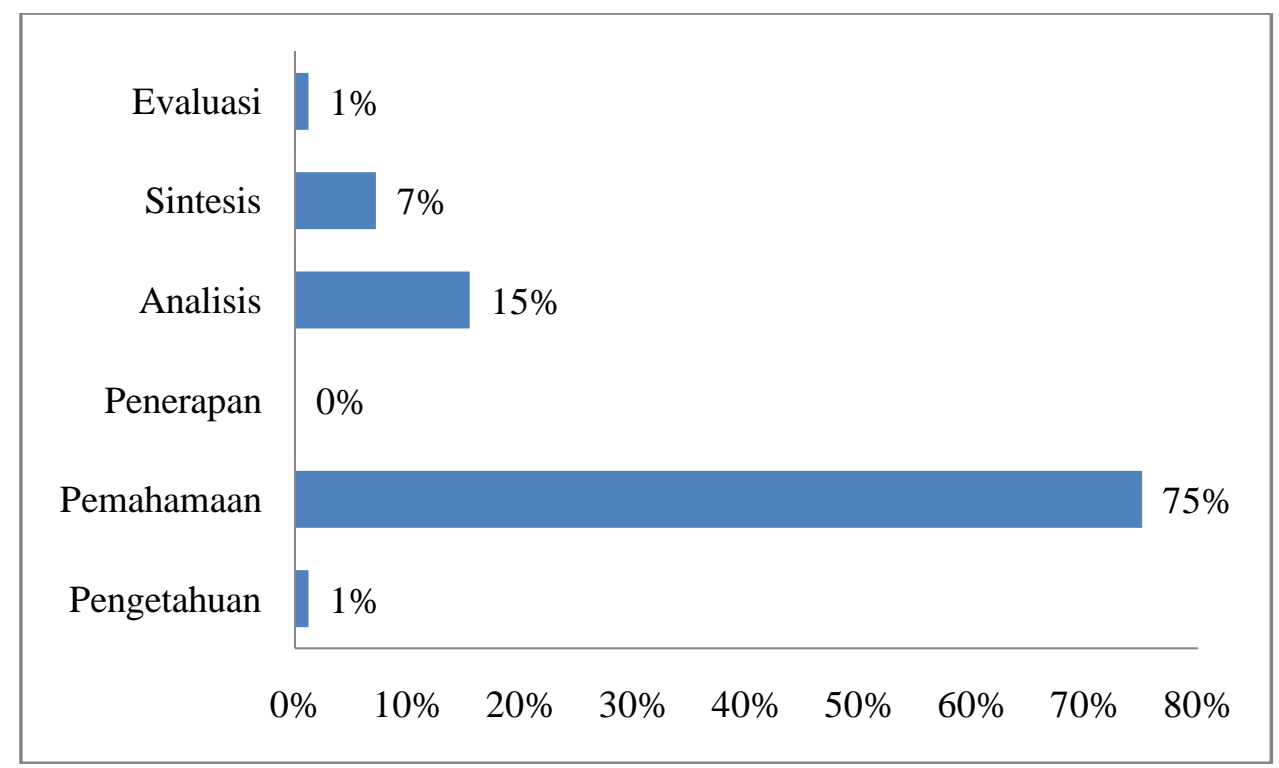

Gambar 4. Diagram Jenjang Kognitif Taksonomi Bloom terhadap Problem Posing Siswa Kategori 5 
Berikut pertanyaan siswa yang termasuk jenjang kognitif evaluasi, yaitu:

"Apakah semakin jauh jaraknya akan semakin mahal?"

Pertanyaan-pertanyaan siswa yang termasuk jenjang kognitif sintesis, yaitu: "Berapa perbandingan antara jarak dan tarif?"

"Berapa perbandingan antara jarak max dan jarak min?"

"Berapa perbandingan antara tarif max dengan tarif min?"

"Berapa perbandingan antara tarif max dengan jarak max?"

"Berapa perbandingan antara tarif min dengan tarif max?"

Pertanyaan-pertanyaan siswa yang termasuk jenjang kognitif analisis, yaitu:

"Bagaimana cara membuat grafik seperti itu?"

"Untuk apa grafik tersebut dibuat?"

"Grafik ini menjelaskan tentang apa?"

"Bagaimana sistem tarif gojek disetiap jarak?"

"Berapa selisih antara tarif max dengan jarak max?"

"Berapa selisih antara tarif min dengan jarak min?"

“Apakah harga ini terus berlanjut ketika $x \rightarrow \infty$ ? Atau berubah pada satu titik?”,

Beberapa Pertanyaan-pertanyaan siswa yang termasuk jenjang kognitif pemahaman, yaitu:

"Berapa tarif gojek setiap $1 \mathrm{~km}$ ?"

“6 km $=15000,7 \mathrm{~km}=17.500$, apakah setiap $1 \mathrm{~km}=2500 ? "$

"Bagaimana tarif yang dikenakan terhadap pelanggan gojek yang menempuh jarak kurang dari satu kilometer?"

"Berapa kenaikan tarif setiap $1 \mathrm{~km}$ ?"

"Berapa tarif gojek per kilometer?"

"Berapa tarif jika menempuh jarak 100 km?"

"Jika kita memiliki uang Rp 20.500, berapa kilo kita bisa capai?"

"Bagaimana jika jarak tempuh $(\mathrm{km})$ bukan bilangan bulat, misal 1,7 km; 2,3 km, berapa harga jasanya?"

Terakhir, pertanyaan siswa yang termasuk jenjang kognitif pengetahuan, yaitu:

"Jaraknya dihitung menggunakan apa?"

Dari hasil angket terbuka yang diberikan menunjukan bahwa $75 \%$ respon siswa menyatakan senang terhadap penyajian materi melalui pendekatan problem posing berbasis GeoGebra. Berikut beberapa alasan mereka, yaitu:

"Saya menjadi paham dan melatih untuk berpikir kritis terhadap sesuatu"

"Saya bisa berperan aktif, baik dengan mengutarakan pertanyaan ataupun pendapat"

"Tidak membosankan"

"Saya dapat mengetahui sesuatu hal yang baru"

"Materinya beda dari yang biasanya"

"Saya bisa merefleksikan suatu soal terhadap keadaan nyata"

"Penyajian materi yang lebih interaktif"

"Komunikatif dan saling menjawab pertanyaan itu mengasyikan"

"Cara ini memancing saya bertanya"

"Suasananya tidak terlalu tegang"

"Setiap pendapat teman-teman diterima" 
Hasil dari item ke-2 angket menunjukkan 58\% siswa tidak binggung terhadap materi yang disajikan, sisanya merasa sebaliknya. Berikut beberapa alasan mereka, yaitu:

"Tidak mengerti tujuan sebenarnya dari materi yang disajikan"

"Untuk apa materi ini diberikan"

"Tidak mengerti dibagian harga tarif dan grafiknya"

"Tiba-tiba kami diberi arahan untuk membuat pertanyaan"

"Penjelasannya tidak rinci"

Hasil dari item ke-3 angket menunjukkan 67\% respon siswa merasa tertantang untuk menjawab pertanyaan yang dibuatnya. Berikut beberapa alasan mereka, yaitu:

"Supaya bisa memecahkan masalah sendiri"

"Saya yang membuat pertanyaan maka saya harus bisa menjawab"

"Rasa penasaran timbul setelah membuat pertanyaan"

"Saya suka pertanyaan yang dibuat"

"Saya mempunyai keingintahuan dan pendapat saya sendiri"

"Pertanyaannya sendiri menantang"

"Saya harus tahu jawabannya dengan bertanya/mencari"

"Saya dapat mengetahui sesuatu yang sebelumnya saya tidak tahu"

"Saya menjadi ingin berpendapat sesuai pikiran dan logika saya"

Hasil dari item ke-4 angket menunjukkan $78 \%$ respon siswa menunjukkan rasa tanggung jawab terhadap pertanyaan yang telah dibuat untuk diselesaikan. Hasil dari item ke-5 angket menunjukkan $23 \%$ siswa menyatakan bahwa materi yang diberikan terkait dengan fungsi, $31 \%$ siswa menyatakan materi tersebut merupakan persamaan linier, sedangkan sisanya menyatakan materi lainnya.

Hasil dari item ke-6 angket menunjukkan $74 \%$ siswa berpendapat bahwa materi yang disajikan berbeda dari penyajian materi yang dilakukan oleh guru mereka sebelumnya. Berikut beberapa alasan mereka, yaitu:

"Penyajian materi lebih menarik karena kita diajak untuk menganalisa terlebih dahulu"

"Pembelajaran kali ini lebih komunikatif dan hampir semua siswa aktif"

"Pada umumnya, guru-guru menyajikan presentasi/materi yang kurang interaktif"

"Bisanya hanya materi soal abstrak yang sulit terpikir oleh logika yang real dalam kehidupan"

"Yang disajikan di sini adalah masalah di kehidupan sehari-hari"

Dari $35 \%$ pertanyaan yang merupakan masalah matematika dan cukup informasi, pertanyaanpertanyaan tersebut belum mengarah pada pertanyaan yang generatif seperti yang dicontohkan dalam Brown dan Walter (2005), yaitu diantaranya:

"Gagasan apa yang terdapat didalam masalah ini?"

“Bagaimana keterhubungannya?'

"Dimana saja kita dapat melihat permasalahan seperti ini?"

"Apakah kami cukup gagasan untuk menyelesaikan masalah tersebut?"

Kemudian, hasil analisis jenjang kognitif taksonomi bloom terhadap pertanyaan tersebut menunjukkan bahwa guru masih sering memberikan soal-soal pemahaman. 
Pada penelitian ini sulit mengkategorikan problem posing yang diajukan siswa yakni membedakan apakah pertanyaan tersebut merupakan kategori 3 atau 4 terlihat dari persentase kategori 3 sebesar 2\% dan kategori 4 sebesar 5\%. Hal ini seperti yang terjadi pada hasil penelitian yang dilakukan oleh Leung (2012).

Hasil angket menunjukkan bahwa siswa senang dalam pembelajaran matematika yang diterapkan pendekatan problem posing dan merasa bertanggung-jawab terhadap pertanyaan yang telah dibuat untuk diselesaikan. Hal ini sesuai dengan apa yang diungkapkan oleh Brown and Walter (1993) dan Silver (1994) (dikutip dalam English, 1997), yaitu bahwa pendekatan ini memberi kesempatan seluas-luasnya bagi siswa untuk mengeksplorasi situasi masalah. Suasana yang tercipta membuat pembelajaran matematika menyenangkan dan produktif. Lebih khusus, problem posing dapat memberikan semangat dan menyebabkan timbulnya berpikir fleksible dan beragam, mendorong para siswa untuk bertanggung jawab atas apa yang mereka pelajari melalui pertanyaan yang mereka buat, mengantisipasi salah paham antara guru dan siswa, memperkaya konsep-konsep dasar, menghilangkan kesalahan sudut pandang dari sifat dasar matematika, dan mengurangi kecemasan dalam belajar matematika. Hasil angket juga menunjukkan bahwa siswa merasa senang dikarenakan materi yang disajikan berupa situasi yang berhubungan dengan kehidupan sehari-hari dan ditampilkan pada Geogebra sehingga materi yang disajikan menjadi lebih interaktif.

\section{KESIMPULAN DAN SARAN}

Dari hasil studi ini dapat disimpulkan bahwa 1) Untuk menghasilkan materi problem posing berbasis komputer, pertama, guru harus memilih konsep yang ingin disampaikan. Kemudian, guru mencari konteks yang sesuai dengan konsep tersebut. Setelah konteks terpilih dan bersesuaian maka dipilihlah software yang tepat untuk merepresentasikan gagasan ke dalam bentuk lain yang dinamis, 2) Dari 240 pertanyaan yang diajukan siswa, hanya 35\% yang merupakan masalah matematika yang masuk akal dan cukup informasi untuk diselesaikan. Dari 35\% pertanyaan tersebut, menunjukkan bahwa $75 \%$ siswa masih dalam tingkat pemahaman berdasarkan taksonomi bloom. Kemudian $75 \%$ respon siswa menyatakan senang terhadap penyajian materi melalui pendekatan problem posing berbasis GeoGebra.

Oleh karena itu, Disain materi perlu dibatasi ruang lingkup problem atau pernyataan yang akan disajikan pada mahasiswa. Bagi guru yang ingin mendesain MPP berbasis komputer, maka guru harus menguasai software yang akan digunakan dan memahami hubungan antara konteks dan konsep yang akan di disajikan. Kemudian, Guru dalam membuat soal sebaiknya bersifat penerapan, analisis, sintesis, dan evaluasi untuk membentuk kebiasaan berpikir siswa.

\section{DAFTAR PUSTAKA}

Beal, C. R. dan Cohen, P. R. 2012. Teach Ourselves: Technology to Support Problem Posing in the STEM Classroom. Published Online in SciRes. Vol. 3, No. 4, 513 - 519. Diakses pada tanggal 13 November 2015, dari http://www.SciRP.org/journal/ce 
Chang, et al. 2011. Embedding game-based problem-solving phase into problem-posing system for mathematics learning. Journal Computers \& Education. Diakses pada tanggal 13 November 2015, dari www.elsevier.com/locate/compedu

Bonotto, Cinzia. 2012. Artifacts as Sources for Problem-Posing Activities. Springer Science+Business Media Dordrecht.

Brown, S. I. dan Walter, M. I., 2005. The Art of Problem Posing, $3^{\text {rd }}$ Ed. New Jersey: Lawrence Erlbaum Associates, Inc.

English, L. D. 1997. Promoting a Problem-Posing Classroom. Proquest Education Journals. United States: NCTM.

Ferrigo, M. Problem Posing in Mathematical Education. Department of Mathematics. Pisa University. Diakses pada tanggal 13 November 2015, dari http://www.dm.unipi.it/ georgiev/club/progects/DYNAMAT/PUBLIC/D10_Disseminat ions/Pisa/13_IT_Nitra_Ferrigo.pdf

Fukuda, C., \& Kakihana, K. (2009). Problem Posing and its Environment with technology. In Proceeding of 33rd conference of Japan Society for Science Education.

Haji, S. 2011. Pendekatan Problem Posing dalam Pembelajaran Matematika di Sekolah Dasar. TRIADIK, 14(1), 55-63.

Herawati, O. D. P., Siroj, R. A., \& Basir, M. D. 2010. Pengaruh Pembelajaran Problem Posing Terhadap Kemampuan Pemahaman Konsep Matematika Siswa Kelas XI IPA SMA Negeri 6 Palembang. Jurnal Pendidikan Matematika, 4(1), 70-80.

Leung, S-K. S. 2012. Teachers Implementing Mathematical Problem Posing in The Classroom: Challenges and Strategies. Springer Science+Business Media B. V.

Robiyana, A. 2013. Eksperimentasi Pembelajaran Matematika Menggunakan Model Problem Posing Materi Segitiga Kelas VII Semester Genap SMP Negeri 16 Purworejo Tahun Pelajaran 2011/2012. EKUIVALEN-Pendidikan Matematika, 3(1).

Stoyanova \& Ellerton, 1996. A framework for research into student's problem posing in school mathematics. Diakses pada tanggal 13 November 2015, dari http:// www.merga.net.au/documents/RP_Stoyanova_Ellerton_1996.pdf

Susanti, E. L., Sukestiyarno, Y. L., \& Sugiharti, E. 2012. Efektivitas Pembelajaran Matematika Dengan Metode Problem Posing Berbasis Pendidikan Karakter. Unnes Journal of Mathematics Education, 1(1).

Sumarmo, U. 2015. Mathematical Problem Posing: Rasional, Pengertian, Pembelajaran, dan Pengukurannya. Pascasarjana STKIP Siliwangi Bandung dan Pascasarjana UPI. Diakses pada tanggal 13 November 2015, dari http://utarisumarmo.dosen.stkipsiliwangi.ac.id/files/2015/09/Problem-Posing-MatematikPengertian-dan-Rasional-2015.pdf

Zakaria, et. al. 2012. Teachers' Creativity in Posing Statistical Problems from Discrete Data. ProQuest Education Journal, Vol. 3, Issue. 8. ISSN: 21514755

Widodo, A., \& Pujiastuti, S. 2006. Profil pertanyaan guru dan siswa dalam pembelajaran sains. Jurnal pendidikan dan pembelajaran, 4(2), 139-148. 